\title{
Numerical and experimental investigations of the two-step clinching process with a bumped die
}

\author{
Chao CHEN*,**,***, Tohru ISHIDA**, Yongfei WANG***, Shengdun ZHAO*** and Xiaolan HAN**** \\ *School of Mechanical and Electrical Engineering, Central South University \\ Changsha 410083, China \\ E-mail: profchenchao@163.com \\ ** Graduate School of Technology, Industrial and Social Sciences, Tokushima University \\ Tokushima 770-8506, Japan \\ ${ }^{* *}$ School of Mechanical Engineering, Xi'an Jiaotong University \\ Xi'an 710049, China \\ ${ }^{* * \star *}$ Mechanical Engineering College, Xi'an Shiyou University \\ Xi'an 710065, China
}

Received: 14 November 2017; Revised: 23 January 2018; Accepted: 10 April 2018

\begin{abstract}
In order to increase the shearing strength and reduce the protrusion height of the clinched joint, a two-step clinching process was designed and investigated in the study. A clinching machine produced by Express Company and extensible dies were used to produce the clinched joint, while a flat die and a bumped die were used to produce the two-step clinched joint. A 2D model in the software DEFORM-2D was applied to analyze the material flow and effective stress distribution of the two-step clinched joint. To validate the numerical model, experimental tests were carried out to get the main geometrical parameters of the two-step clinched joint. The two-step clinching method could increase the neck thickness with the decrease of the protrusion height. Shearing tests were carried out to obtain the shearing strengths of the two-step clinched joints. The results showed that the shearing strength and energy absorption of the joint could be increased by the two-step clinching process because of the increased neck thickness. The two-step clinching method was proved to be effective for increasing the shearing strength and energy absorption of the clinched joint.
\end{abstract}

Keywords : Two-step clinching, Deform, Material flow, Strength, Energy absorption

\section{Introduction}

To build the lightweight structures of the automobiles, the use of lightweight materials such as magnesium alloy and aluminum alloy tends to increase in recent years. One of the widely used joining methods for the automotive structures is the spot welding technology. However, it is difficult to join aluminum alloy sheets using the welding technology. The high thermal conductivity, oxide coating, and other properties of aluminum alloy may have a bad influence on the welding process.

A special rivet is used in the self-pierce riveting process to join the metal sheets. The joint can get a high shearing strength using the special rivet. However, the special rivet required in the joining process may increase the weight and cost of the joint, which is not suitable to be used for building the lightweight automotive structures. The special rivet will also damage the upper sheet by impaling the upper sheet. In addition, the relatively high costs of the rivets as well as high joining loads also limit the wide use of the self-pierce riveting process.

There is no rivet applied in the mechanical clinching process. So the mechanical clinching is suitable for building the lightweight structures. The mechanical clinched joint uses a special mechanical interlock to hook the sheets together. The interlock can be produced by plastic deformation in the clinching process (Chen et al., 2017a). The mechanical clinching process has the advantages of environmental protection, energy saving, no pre-punching, no light, no smoke, and no damage on the upper sheet.

In recent years, many researchers pay attention to investigate the mechanical clinching process. The mechanical properties of the clinched joint are mainly affected by joining process, joining tools, joining equipment, and joining parts. The clinching tools are one of the important factors for the clinching process to produce an eligible clinched joint. Oudjene et al. (2009) carried out a shape optimization of the clinching dies using the response surface methodology with Moving Least-Square approximation. The punch and die were optimized to improve the resistance to 
tensile loading of the joint. Lee et al. (2010) also proposed a design method of mechanical clinching tools. Han et al. (2016) used an orthogonal experimental design method to optimize the geometrical parameters of the clinching tools. The joining parameters, including sliding distance, punch corner radius, bottom thickness, and die depth were numerically optimized using the Deform-2D.

Lambiase (2013) investigated the material flow during the mechanical clinching process. The interlock is formed by plastic deformation. Chen et al. (2017b) took the interlock and neck thickness as the main quality parameters. Formability of the materials may be a problem for the clinching process. Lambiase et al. (2015) proposed sheets preheating method to increase the material formability. Lambiase (2015) also used the concurrent employment of dies geometry modifications and pre-heating to control the material flow.

In terms of basic geometrical shapes, different shapes of clinching dies like fixed die and extensible die are investigated to obtain higher strength. There are many advantages of extensible die over fixed die. Firstly, the employment of the extensible dies can reduce the forming loads and increase the joining strength (Lambiase and Di Ilio, 2014). Secondly, a better interlock can be produced by the extensible dies with the material flow radially (He et al., 2014a). Thirdly, extensible dies are flexible to join different metal sheets with a wide range of sheet thickness. Furthermore, there is no build-up material in the clinching dies after the clinching process, which makes it easy to maintain the dies. So the extensible dies are widely used in the mechanical clinching process.

Many different materials can be joined together by the mechanical clinching process. Xing et al. (2015) investigated the joining of copper alloy H62 sheets by mechanical clinching. Zhang et al. (2017) used clinching process to join titanium alloy sheets with the heat treatment. Chen et al. (2016a) investigated the mechanical properties of the clinched joint with aluminum alloy sheet. Abe et al. (2014) solved the problem for joining ultra-high strength steel sheets using mechanical clinching process. The clinched joint with ultra-high strength steel could get superior fatigue strength. Lambiase et al. (2016a, b) investigated the feasibility of mechanical clinching process for joining aluminum alloy and Fiber Reinforced Polymer. The clinching process is a joining method using the mechanical properties of the sheet materials without consideration of the chemical properties and thermal properties, so this joining technique has a very wide range of application scope.

In order to save the experimental resources, many efforts have been spent to investigate the clinching process by finite element simulation. Lambiase and Di Ilio (2013) carried out a finite element analysis of the material flow in the clinching process. Hame et al. (2000) built a finite element model to simulate the clinching process with automatic remeshing. Large mesh distortions could be avoided by the remeshing method. Coppieters et al. (2013) built a numerical model to predict strength of the clinched joint under multi-axial loading. In order to evaluate the strength of the clinched joint by loading the sheets vertically, Eshtayeh and Hrairi (2016) used LS-DYNA explicit and implicit finite element software to simulate the clinching process.

However, there is an obvious disadvantage of the clinched joint with the exterior protrusion. The high protrusion could affect the wide application of the clinched joint on the automotive structures. The clinched joint with a high protrusion can't be applied in the visible areas where a lower protrusion or a flat surface is required. In order to get a lower protrusion, some improved clinching processes were proposed and investigated.

Gerstman and Awiszus (2014) investigated a new joining technology named flat-clinching technology to join the sheets with a flat surface. There was no die-sided protrusion extending out of the metal plane. However, a higher force on the blank holder was required to fix the sheets on the flat die in the process of flat-clinching. Neugebauer et al. (2008) discussed the dieless mechanical clinching process. A lower protrusion was produced in the dieless clinching prcess. Nevertheless, the force and displacement of the punch must be precisely controlled in the dieless clinching process, which made the operation complex. Chen et al. (2016b) designed a special clinch-rivet to reduce the protrusion height and increase the strength of the clinched joint. This process was proved effective for the clinched joint. However, an additional rivet was required in the process, which may increase the weight and cost of the clinched joint. Chen et al. (2016c) used the second step to reduce the protrusion height of the clinched joint. The protrusion height was reduced from 1.62 to $0.94 \mathrm{~mm}$. Chen et al. (2016d) also used different reshaping forces to carry out the second step. Higher reshaping force contributed to reduce the protrusion height. Another advantage of the second step is to increase the strength of the clinched joint (Chen et al., 2017c). Lambiase and Ko (2017) also used the two-step clinching process to join aluminum and Carbon Fiber Reinforced Polymer, which contributed to increase the joint strength. Chen et al. (2017d) also investigated the two-step clinching process for joining dissimilar aluminum alloy sheets.

In the current study, a two-step clinching process was investigated to improve the appearance and mechanical 
properties of the clinched joint. Extensible dies were used to produce the clinched joint, while a flat die and a bumped die were used to produce the two-step clinched joint. DEFORM-2D was applied to carry out the numerical simulation of the material flow and effective stress distribution of the two-step clinched joints. To validate the numerical model, experimental tests were carried out to get the main geometrical parameters of the two-step clinched joint. Shearing tests were also carried out to get the shearing strengths of the two-step clinched joints. The two-step clinching method was proved to be effective for increasing the shearing strength and energy absorption of the clinched joint.

\section{Mechanism of the two-step clinching process}

\subsection{First step: mechanical clinching process}

As can be seen from Fig. 1, a fundamental clinched joint can be produced with extensible dies in the mechanical clinching process. Severe plastic deformation is generated on the sheets to form a mechanical interlock. With the mechanical interlock, the sheets can be joined together. Initially, the punch moves down to compress the sheets and generates localized plastic deformation of the sheets. Then the material of the sheets flows radially along the radial sliding direction of die sectors after the lower sheet contacts the anvil. The material continues to spread until the mechanical interlock is generated.

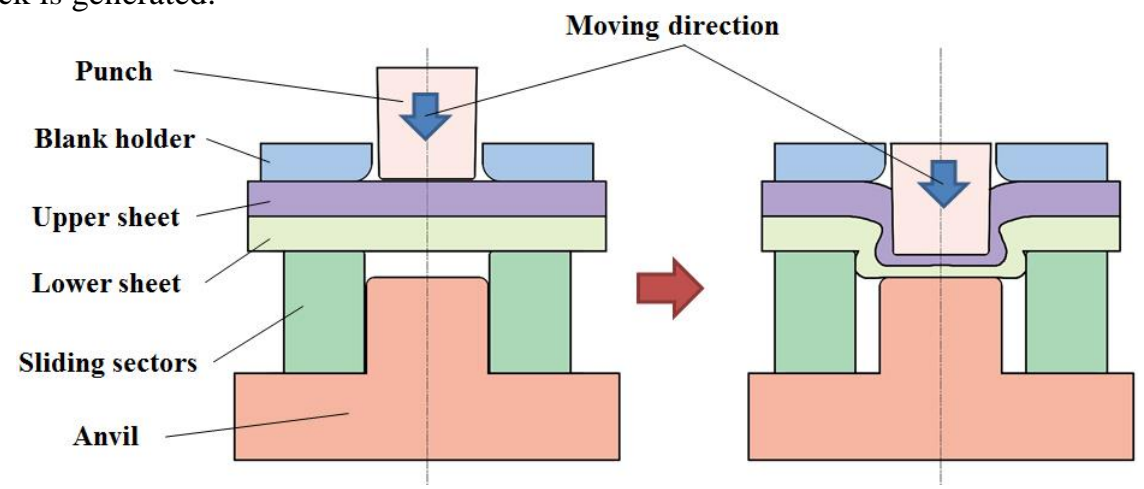

Fig. 1 Mechanical clinching process

\subsection{Second step: reshaping process}

As can be seen from Fig. 2, the fundamental clinched joint is reshaped with a flat die and a bumped die in the reshaping process. The bump of the bumped die was used to support the clinched joint. The lower flat die is used to compress the protrusion of the clinched joint. With the movement of the lower flat die, the protrusion height of the clinched joint can be reduced. The bump on the bumped die is used to control the material flow of the clinched joint in the reshaping process. After the reshaping process, the mechanical interlock is strengthened with better mechanical properties.

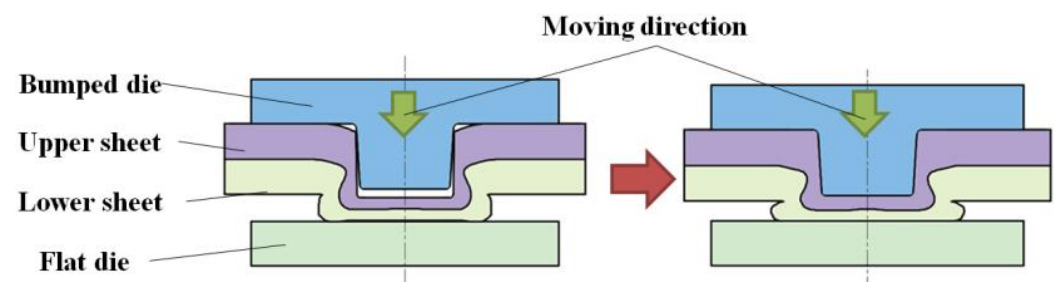

Fig. 2 Reshaping process

\section{Experimental procedure}

\subsection{Material of the sheets}

A15052 is widely used to build the automotive structures in recent years. So A15052 was used as the material of the sheet in this study. All of the sheets were cut from a large unique plate along the rolling direction. The width of the sheet is $25 \mathrm{~mm}$, thickness is $1.9 \mathrm{~mm}$, and the length is $80 \mathrm{~mm}$. Instron 5982 testing machine was used to measure the mechanical properties of the Al5052 sheet. According to the measured results, the yield strength of the Al5052 is 185 $\mathrm{MPa}$, the poisson ratio is 0.33 , and the elastic modulus is $62.7 \mathrm{GPa}$. Material flow stress is described by Hollomon model as $\sigma=351 \varepsilon^{0.12} \mathrm{MPa}$. The elongation at break of the Al5052 is $18 \%$. Al5052 sheet has better ductility, which is suitable to be used in the clinching experiment.

\subsection{First step: mechanical clinching process}

A clinching machine produced by Express Company was used to carry out the mechanical clinching process. As shown in Fig. 3, extensible dies were used as the clinching tools in this study. The extensible dies consist of punch, 
blank holder, anvil, and sliding sectors. The punch was used to compress the sheets, and the blank holder was used to fix the sheets on the sliding sectors. Three sliding sectors were used to guide the material flow of the clinched joint in the clinching process. The punch could move downward with a speed of $0.5 \mathrm{~mm} / \mathrm{s}$, and the anvil was fixed.

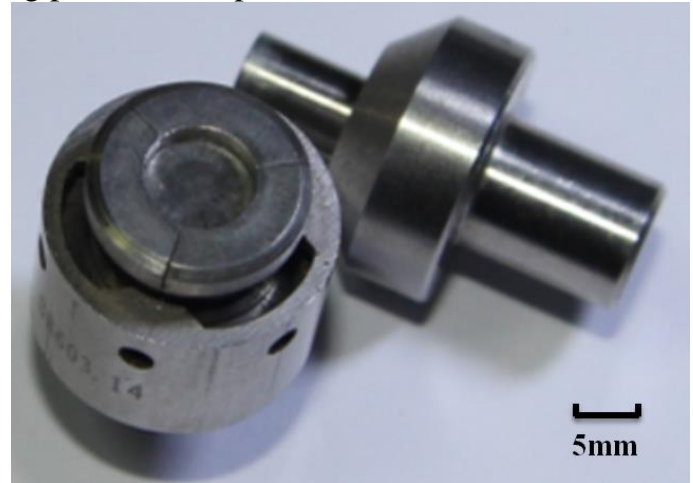

(a) Dies

Fig. 3 Extensible dies

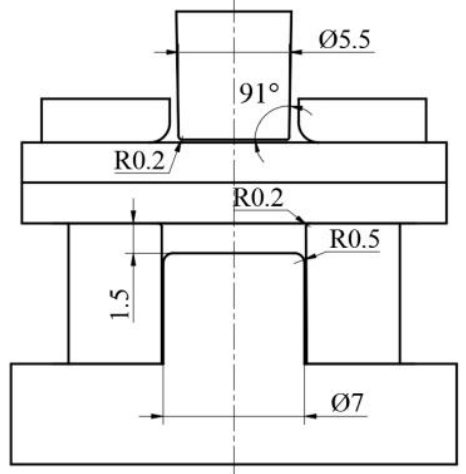

(b) Geometrical parameters

By controlling the displacement of the punch, different clinched joints with different geometrical parameters can be produced. In this study, the clinched joints with bottom thicknesses of 1.4, 1.5, and 1.6 mm were produced to investigate the influence of the bottom thickness on the mechanical properties of the joint.

\subsection{Second step: reshaping process}

A hydraulic servo press with a maximum load of $160 \mathrm{kN}$ was used to carry out the reshaping process. As shown in Fig. 4, a flat die and a bumped die were used to produce the two-step clinched joint. The pit of the conventional clinched joint was placed on the bumped die. The load of the servo press was set to $25 \mathrm{kN}$, and the speed of the flat die was set to $0.05 \mathrm{~mm} / \mathrm{s}$.

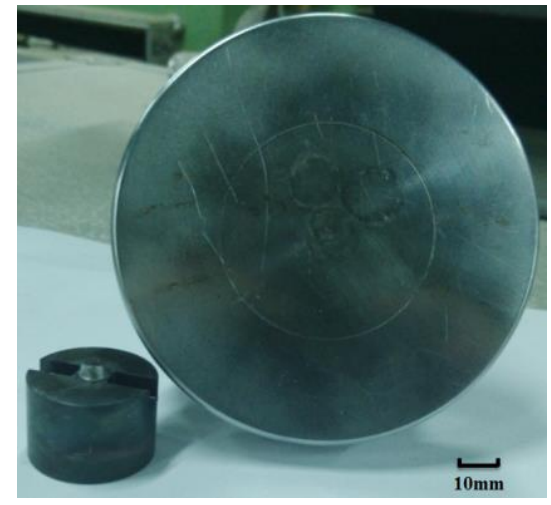

(a) Dies

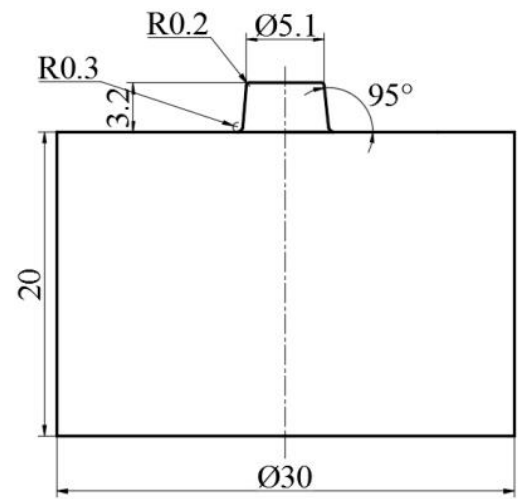

(b) Geometrical parameters

\subsection{Strength test}

Fig. 4 Flat die and bumped die

Many researchers use the shearing strength to evaluate the quality of the clinched joint. He et al. (2014b), Lambiase, F. and Di Ilio, A. (2015) used the shearing test to get the shearing strength. In this study, shearing test was carried out to get the shearing strengths of the conventional clinched joint and the two-step clinched joint. Instron 5982 testing machine was used to carry out the shearing strength test. The specimen used for the shearing strength test is shown in Fig. 5. The clinched joint was located on the center of the overlap of the A15052 sheets. The lower sheet was fixed, and the upper sheet was pulled to move downward until the joint was fractured. The speed of the shearing strength was set to $2 \mathrm{~mm} / \mathrm{min}$. The maximum force can be measured by the testing machine. The maximum force in the shearing test was taken as the shearing strength of the joint.

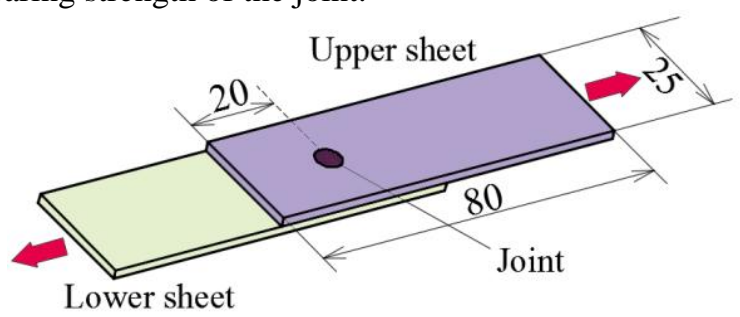


Fig. 5 Specimen used for the shearing test

The whole experimental plan can be summarized in Table 1.

Table 1 Experimental plan

\begin{tabular}{|c|c|}
\hline Step number & Experiment \\
\hline Frist step & Mechanical clinching process \\
\hline Second step & Reshaping process \\
\hline Third step & Shearing test \\
\hline
\end{tabular}

\section{Finite element simulation and conditions}

The purpose of the finite element simulation is to investigate the material flow and stress distribution in the two-step clinching process. It is not convenient to show the material flow and stress distribution in the experiment. In order to save resource and time, finite element simulation with the famous metal forming simulation software Deform was carried out to simulate the two-step clinching process. A model of 3D may lead to a longer simulating time because of a larger number of elements. The two-step clinched joint, extensible dies used in the first step, flat die and bumped die used in the second step are all axisymmetric. So a 2D numerical model with a small number of elements was built to simulate the two-step clinching process, which can reduce the time and cost.

The fundamental clinching process was simulated first with extensible dies. Plastic material models were used to assume the sheets, and rigid models were used to assume the extensible dies. Quadrilateral elements were used to mesh the sheets. Automatic remeshing method was also used to avoid the serve mesh distortion in the simulation of the clinching process. The geometrical parameters of the extensible dies in the numerical simulation were kept consistent with those used in the clinching experiment. The numerical model for the first step, mechanical clinching process, is shown in Fig. 6. The speed of the punch was $0.5 \mathrm{~mm} / \mathrm{s}$. The coulomb friction model was chosen for the contact between the sheets and extensible dies with a friction coefficient of 0.15 (Chen et al., 2017e), and the friction coefficient between the Al5052 sheets was set as 0.3 (Wen et al., 2014). The simulation step number was set to 78, 80, and 82, respectively. The time increment is $0.1 \mathrm{~s}$. Automatic remeshing technology was also used to prevent the mesh distortion in the finite element simulation.

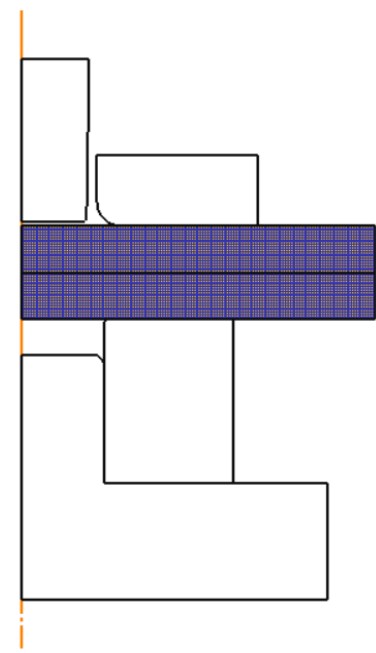

Fig. 6 Numerical model for the first step, mechanical clinching process

The second process was continued to simulate by changing the extensible dies to flat die and bumped die in the same software after the first process. The flat die and bumped die were taken as rigid model. The coulomb friction model was chosen for the contact between the sheets and dies with a friction coefficient of 0.15 , and the friction coefficient between the Al5052 sheets was set as 0.3. The numerical model for the second step, reshaping process, is shown in Fig. 7. The speed of the flat die was set to $0.05 \mathrm{~mm} / \mathrm{s}$, and the bumped die was fixed. 


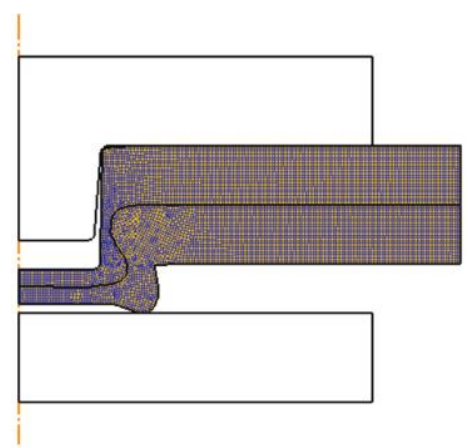

Fig. 7 Numerical model for the second step, reshaping process

\section{Results and discussion}

\subsection{Failure mode}

The main geometrical parameters of the clinched joint are shown in Fig. 8. The geometrical parameters of the clinched joint, such as bottom thickness, interlock, and neck thickness, have an important influence on the mechanical properties of the clinched joint, so the main geometrical parameters are taken into consideration in this study.

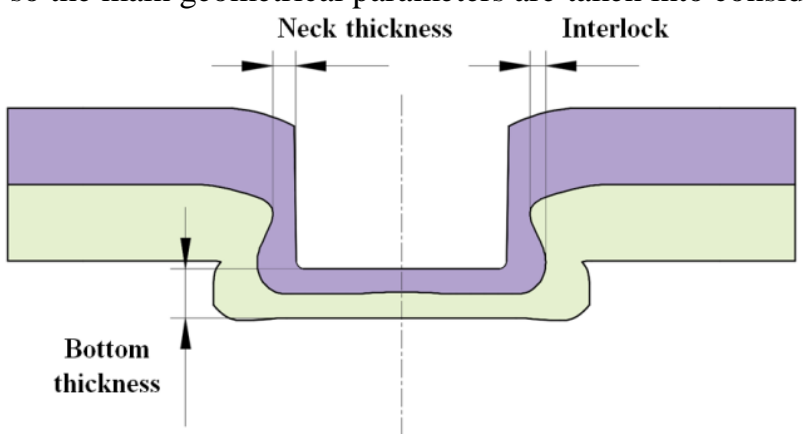

Fig. 8 Main geometrical parameters of the clinched joint

The failure modes of the clinched joint and two-step clinched joint are shown in Fig. 9. Both the clinched joint and the two-step clinched joint were failed as the neck fracture mode in the shearing test. The failure mode was not changed by the two-step clinching process. In the shearing test, the shearing force was mainly applied on the neck area because of the mechanical interlock to hook the sheets. The initial damage developed from the interfacial surface of the clinched joint and subsequent crack propagation along the neck leaded to neck fracture.

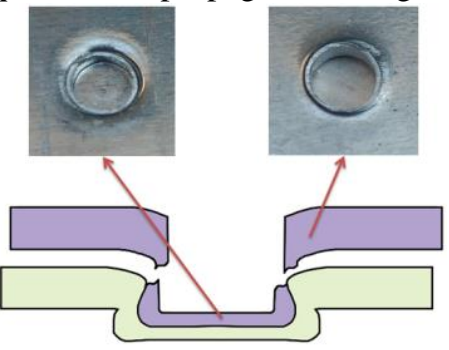

(a)

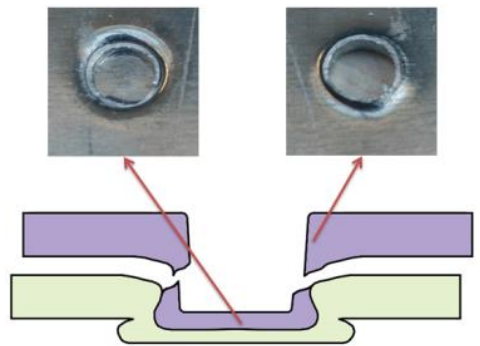

(b)

Fig. 9 Neck fracture mode in the shearing test: (a) clinched joint (b) two-step clinched joint

\subsection{Numerical model validation}

In order to obtain accurate numerical results, the numerical model validation should be carried out before analyzing the numerical results. The experimental results and numerical predictions of the geometrical parameters are compared using the same processing parameters to validate the numerical model. Both the clinched joint and the two-step clinched joint are failed as the neck fracture mode in the shearing test, which means the neck thickness is the main geometrical parameter for the two-step clinched joint in this study.

Many researchers evaluate the joining quality of the clinched joint by measuring the bottom thickness. Bottom thickness was taken as the independent variable to produce different clinched joints used for numerical validation, and the main geometrical parameter, neck thickness was taken as the dependent variable. The experimental results and numerical predictions of the clinched joints with different geometrical parameters are shown in Fig. 10. As can be seen, the experimental results and numerical predictions are in good agreement. Thus, the numerical model is proved to be accurate for evaluating the material flow and stress distribution of the two-step clinched joint. 


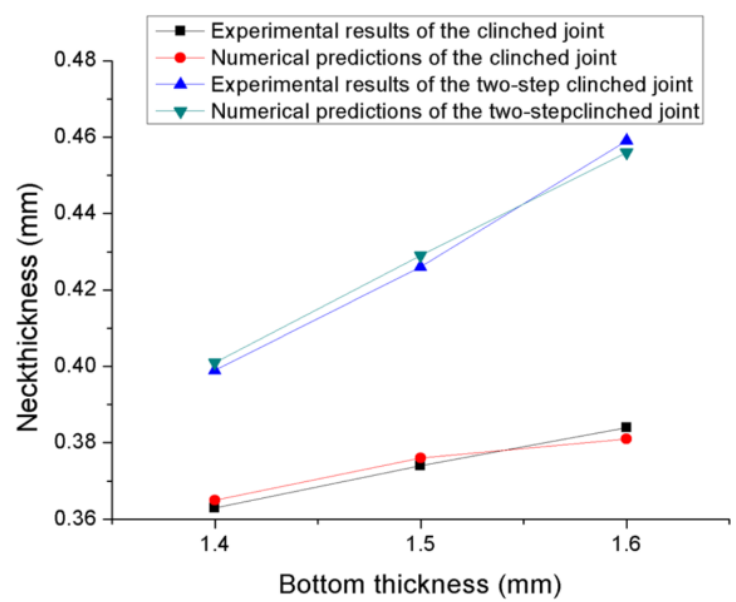

\subsection{Material flow}

Fig. 10 Comparison of the experimental results and numerical predictions about the neck thickness

After the numerical model validation, the numerical results are used to show the material flow and stress distribution of the two-step clinching process. The material flow and stress distribution of the clinched joint in the first step, mechanical clinching process, are shown in Fig. 11.

The plastic deformation for producing the clinched joint was mainly occurred in the cavity volume surrounded by the anvil, sliding sectors, and punch. Initially, the punch moved downward to compress the sheets. Then the two sheets tended to deform along the direction of the punch movement. With the material flow downward and radially, the sliding sectors were pushed to slide along the radial direction, which enlarged the cavity volume for the plastic deformation of the two sheets. The material of the two sheets would spread radially with the radial movement of the sliding sectors after the lower sheet contacted the anvil. The punch continued moving downward to compress the sheets until the mechanical interlock was produced. With the mechanical interlock to hook the sheets, the conventional clinched joint was produced. The main effective stress reached the highest at the bottom part of the clinched joint, where the severe plastic deformation occurred. The bottom part of the clinched joint mainly bore the clinching force on the punch, so the effective stress could reach the highest in the mechanical clinching process.
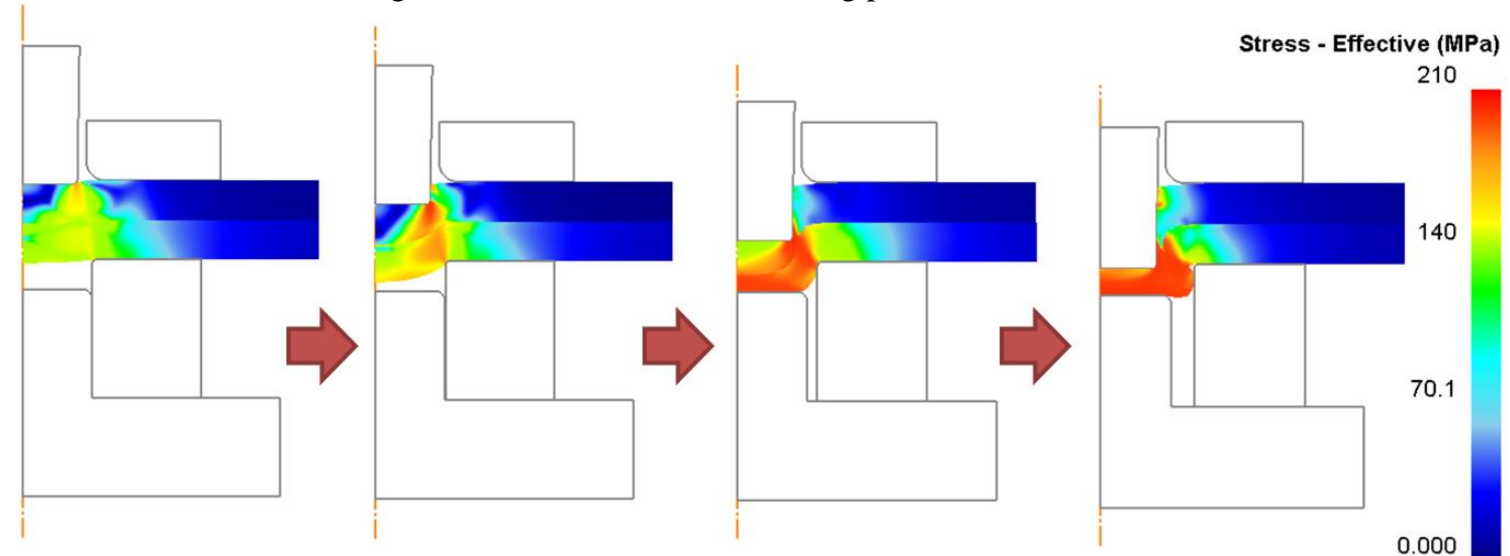

Fig. 11 Material flow and stress distribution of the clinched joint in the first step, mechanical clinching process

The material flow and stress distribution of the two-step clinched joint in the second step, reshaping process, are shown in Fig. 12. In the second step, the conventional clinched joint produced in the first step was reshaped by compressing the high protrusion. Initially, the pit of the conventional clinched joint with a high protrusion was placed on the bump on the bumped die. The upper flat die moved down to compress the high protrusion of the clinched joint. The bump on the bumped die could support the clinched joint and adjust the material flow in the reshaping process. The protrusion height was reduced by being compressed in the second step, and the neck thickness was increased. The main effective stress reached the highest at the protrusion part and neck area of the two-step clinched joint, where the severe plastic deformation occurred. The protrusion part of the two-step clinched joint mainly bore the reshaping force in the mechanical clinching process, so the effective stress could reach the highest. The neck of the clinched joint was also deformed under the reshaping process to increase the neck thickness, so the effective stress could also reach the highest in the final phase. 


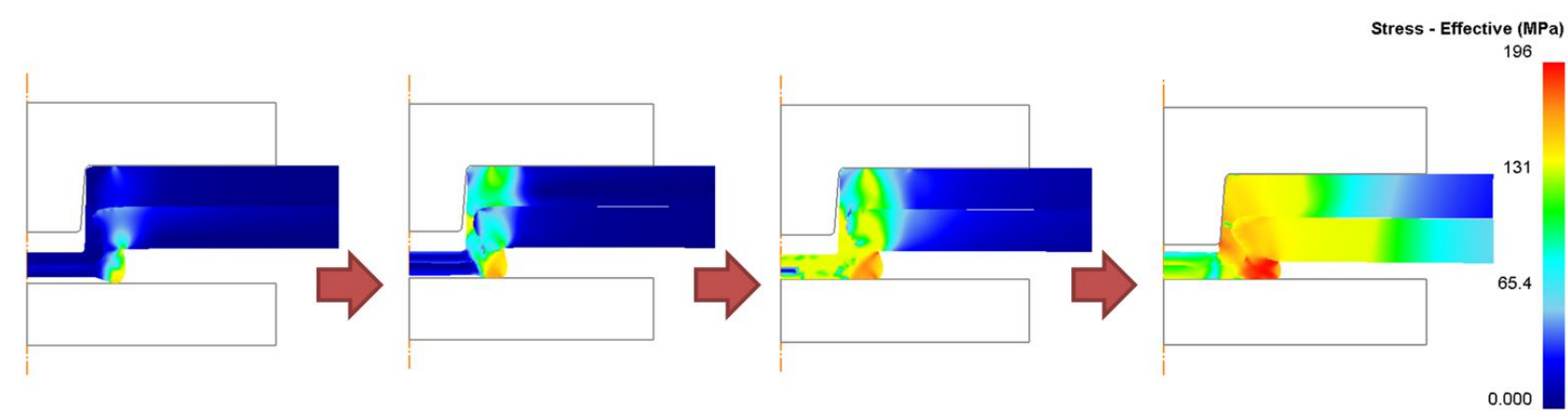

Fig. 12 Material flow and stress distribution of the two-step clinched joint in the second step, reshaping process

After the second step, the two-step clinched joint can be produced. A two-step clinched joint with a bottom thickness of $1.6 \mathrm{~mm}$ is shown in Fig. 13. As can be seen, the mechanical interlock was not damaged after the second step. The protrusion height of clinched joint was reduced, and the interlock was strengthened. During the reshaping step, the bottom part of the joint is less constrained. This region is mainly subjected to upsetting that promotes an increase in interlock (Lambiase, F. and Ko, D.C., 2017).

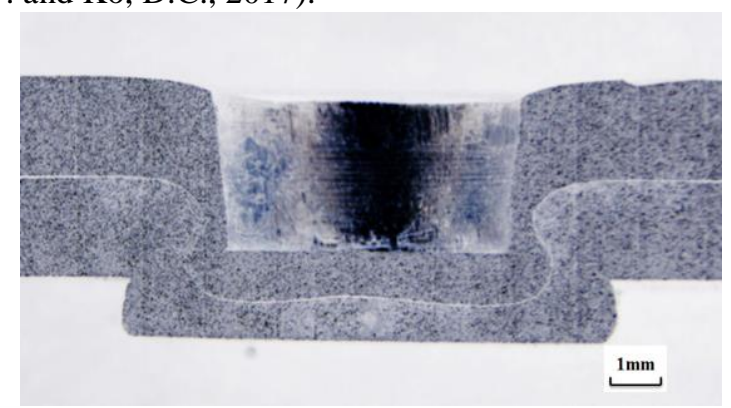

\subsection{Shearing strength}

Fig. 13 Two-step clinched joint with a bottom thickness of $1.6 \mathrm{~mm}$

In the shearing test, five specimens were tested to get the average shearing strength for each joining condition. The shearing strengths of the conventional clinched joints and two-step clinched joints with different bottom thicknesses are shown in Fig. 15.

For the clinched joint with a bottom thickness of $1.6 \mathrm{~mm}$, the shearing strength of the two-step clinched joint was increased by $26.6 \%$ compared with that of the conventional clinched joint. For the clinched joint with a bottom thickness of $1.5 \mathrm{~mm}$, the shearing strength of the two-step clinched joint was increased by $31.5 \%$ compared with that of the conventional clinched joint. For the clinched joint with a bottom thickness of $1.4 \mathrm{~mm}$, the shearing strength of the two-step clinched joint was increased by $33.5 \%$ compared with that of the conventional clinched joint. As can be seen, all of the two-step clinched joints have higher shearing strengths than the clinched joint, which proved that the two-step clinching process was feasible to increase the shearing strength of the clinched joint.

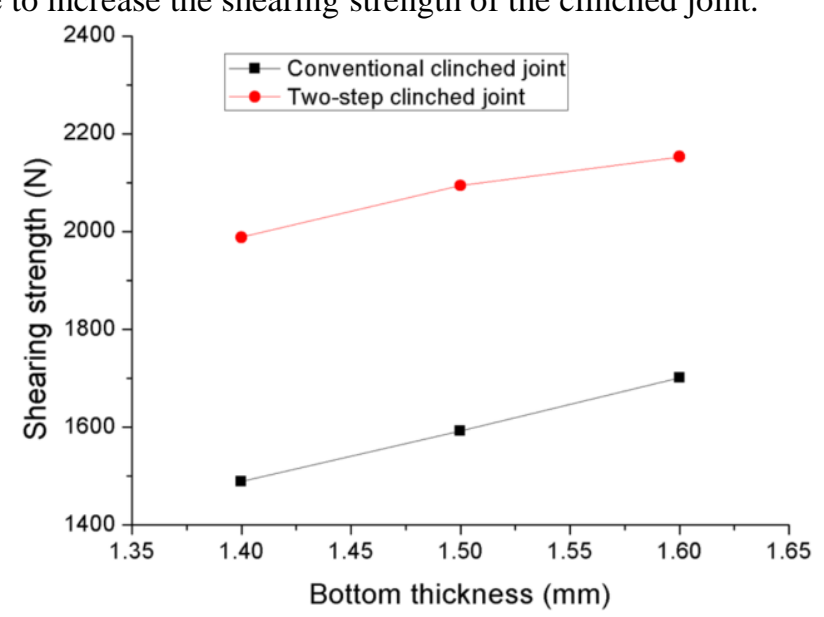

Fig. 15 Shearing strengths of the conventional clinched joints and two-step clinched joints

As shown in Fig. 11, the neck thickness of the clinched joint could be increased by the two-step clinching process. For the clinched joint failed as the neck fracture mode in the shearing test, the neck thickness has an important influence on the shearing strength of the clinched joint. The increase of the neck thickness contributed to the increase of 
the shearing strength of the two-step clinched joint.

The shearing force-displacement curves of the clinched joints are shown in Fig. 16. All of the curves have similar developing trend.

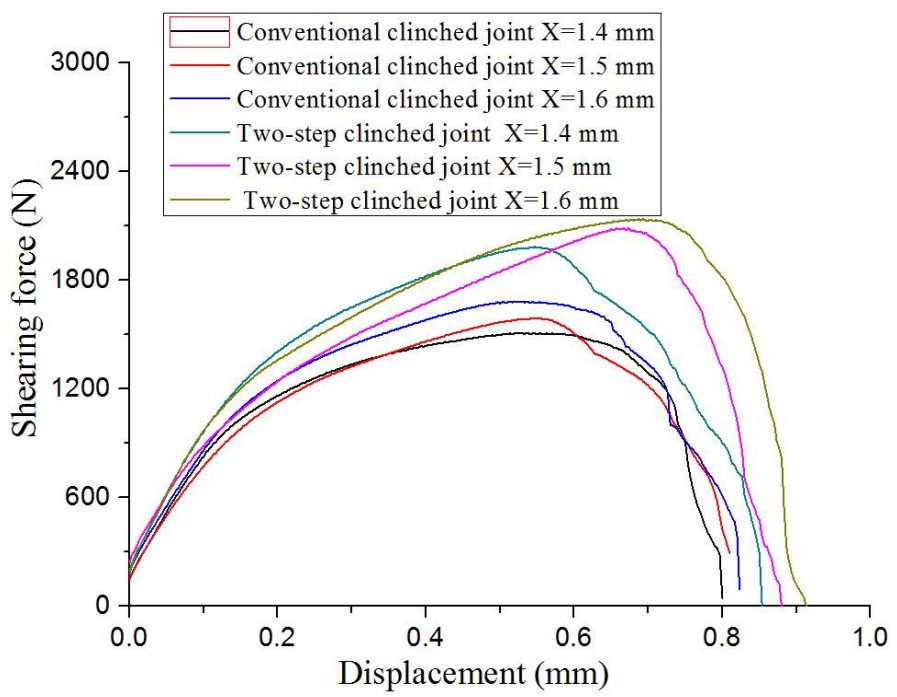

Fig. 16 Shearing force-displacement curves of the joints

In this study, a flat die and a bumped die were used to reshape the clinched joint. Compared with the reshaped joint with two flat die (Chen et al., 2017f), the two-step clinched joint with a flat die and a bumped die can get higher strength.

\subsection{Energy absorption}

Energy absorption in the failure process is another parameter to evaluate the safety of the clinched joint (Chen et al., 2017g). It is better for the clinched joint to absorb more energy in the failure process. For example, if a car was hit on the road, the automotive structure and the joint should has the ability to absorb more impact energy in the hitting process to protect the safety of the driver. So the energy absorption was taken as an essential evaluation criterion for the clinched joint. The areas between the abscissas and force-displacement curves were measured to get the energy absorption values of different clinched joints. The energy absorption of the conventional clinched joints and two-step clinched joints with different bottom thicknesses are shown in Fig. 17.

For the clinched joint with a bottom thickness of $1.6 \mathrm{~mm}$, the shearing strength of the two-step clinched joint was increased by $35.5 \%$ compared with that of the conventional clinched joint. For the clinched joint with a bottom thickness of $1.5 \mathrm{~mm}$, the shearing strength of the two-step clinched joint was increased by $35.8 \%$ compared with that of the conventional clinched joint. For the clinched joint with a bottom thickness of $1.4 \mathrm{~mm}$, the shearing strength of the two-step clinched joint was increased by $37.4 \%$ compared with that of the conventional clinched joint. As can be seen, all of the two-step clinched joints have higher energy absorption than the clinched joint, which proved that the two-step clinching process was feasible to increase the energy absorption of the clinched joint.

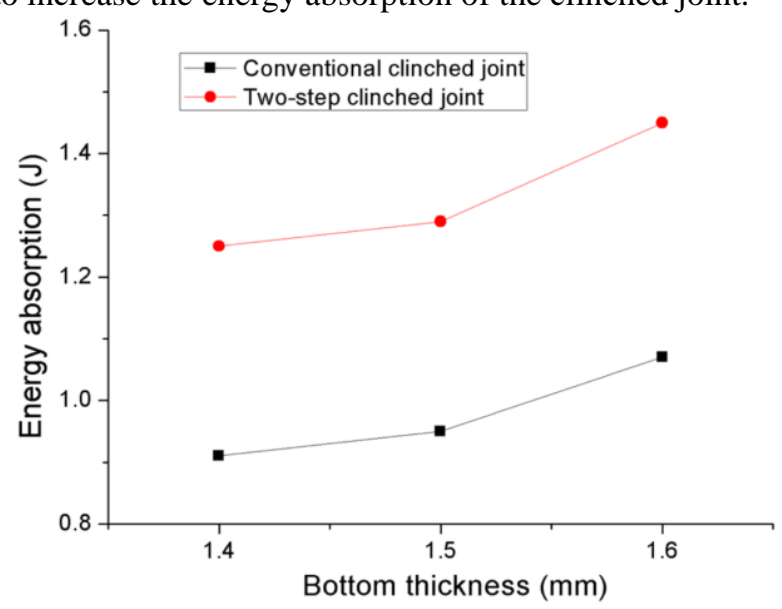

Fig. 17 Energy absorption of the conventional clinched joints and two-step clinched joints

\section{Conclusion}


In the current study, a two-step clinching process was designed and investigated to improve the appearance and mechanical properties of the clinched joint. Extensible dies were used to produce the clinched joint, while a flat die and a bumped die were used to produce the two-step clinched joint. DEFORM-2D was applied to carry out the numerical simulation of the material flow and effective stress distribution of the two-step clinched joints. The main conclusion of this study can be drawn as follows:

(1) Both the conventional clinched joint and the two-step clinched joint were failed as the neck fracture mode in the shearing test, which means the neck thickness was the main geometrical parameter for evaluating the joining quality of the clinched joint.

(2) The experimental results and numerical predictions were in good agreement. The numerical model was proved to be accurate to carry out the finite element simulation.

(3) The clinched joint was produced with a mechanical interlock which was generated by the material flow in the clinching process. The material of the protrusion was compressed to flow downward by the flat die, which resulted in the decrease of the protrusion height and increase of the neck thickness.

(4) All of the two-step clinched joints had higher shearing strength and energy absorption than the clinched joint, which proved that the two-step clinching process was feasible to increase the shearing strength and energy absorption of the clinched joint.

\section{Acknowledgement}

The research work is supported by the National Natural Science Foundation of China (Grant No. 51805416) and National Natural Science Foundation of China (Grant No. 51675414).

\section{References}

Abe, Y., Kato, T., Mori, K. and Nishino, S., Mechanical clinching of ultra-high strength steel sheets and strength of joints, Journal of Materials Processing Technology, Vol. 214, No. 10 (2014), pp.2112-2118.

Chen, C., Zhao, S.D., Cui, M.C., Han, X.L. and Fan, S.Q., Mechanical properties of the two-steps clinched joint with a clinch-rivet, Journal of Materials Processing Technology, Vol.237 (2016a), pp.361-370.

Chen, C., Zhao, S.D., Han, X.L., Cui, M.C. and Fan, S.Q., Optimization of a reshaping rivet to reduce the protrusion height and increase the strength of clinched joints, Journal of Materials Processing Technology, Vol.234 (2016b), pp.1-9.

Chen, C., Zhao, S.D., Cui, M.C., Han, X.L., Fan, S.Q. and Ishida, T., An experimental study on the compressing process for joining Al6061 sheets, Thin-Walled Structures, Vol. 108 (2016c), pp.56-63.

Chen, C., Zhao, S.D., Han, X.L., Cui, M.C. and Fan, S.Q., Investigation of mechanical behavior of the reshaped joints realized with different reshaping forces, Thin-Walled Structures, Vol. 107 (2016d), pp.266-273.

Chen, C., Zhao, S.D., Han, X.L., Cui, M.C. and Fan, S.Q., Investigation of the height-reducing method for clinched joint with AL5052 and AL6061, The International Journal of Advanced Manufacturing Technology, Vol. 89 (2017a), pp.2269-2276.

Chen, C., Zhao, S.D., Han, X.L., Cui, M.C. Zhao, X.Z. and Ishida, T., Experimental investigation of the mechanical reshaping process for joining aluminum alloy sheets with different thicknesses, Journal of Manufacturing Processes, Vol. 26 (2017b), pp.105-112.

Chen, C., Fan, S.Q., Han, X.L., Zhao, S.D., Cui, M.C., and Ishida, T., Experimental study on the height-reduced joints to increase the cross-tensile strength, The International Journal of Advanced Manufacturing Technology, Vol. 91 (2017c), pp.2655-2662.

Chen, C., Han, X.L., Zhao, S.D., Xu, F., Zhao, X.Z. and Ishida, T., Comparative study on two compressing methods of clinched joints with dissimilar aluminum alloy sheets, The International Journal of Advanced Manufacturing Technology, Vol. 93 (2017d), pp.1929-1937.

Chen, C., Zhao, S.D., Han, X.L., Wang, Y.F. and Zhao, X.Z., Investigation of flat clinching process combined with material forming technology for aluminum alloy, Materials, Vol. 10 (2017e), No. 1433.

Chen, C., Zhao, S.D., Cui, M.C., Han, X.L. and Ben, N.Y., Numerical and experimental investigations of the reshaped joints with and without a rivet, The International Journal of Advanced Manufacturing Technology, Vol. 88 (2017f), pp.2039-2051.

Chen, C., Zhao, S.D., Han, X.L., Zhao, X.Z. and Ishida, T., Experimental investigation on the joining of aluminum alloy sheets using improved clinching process, Materials, Vol. 10 (2017g), No. 887. 
Coppieters, S., Lava, P., Van Hecke, R., Cooreman, S., Sol, H., Van Houtte, P. and Debruyne, D., Numerical and experimental study of the multi-axialquasi-static strength of clinched connections, International Journal of Material Forming, Vol. 6 (2013), pp.437-451.

Eshtayeh, M. and Hrairi, M., Multi objective optimization of clinching joints quality using Grey-based Taguchi method, The International Journal of Advanced Manufacturing Technology, Vol. 87 (2016), pp.233-249.

Gerstmann, T. and Awiszus, B., Recent developments in flat-clinching, Computational Materials Science, Vol.81 (2014), pp.39-44.

Han, X.L., Zhao, S.D., Liu, C., Chen, C. and Xu, F., Optimization of geometrical design of clinching tools in clinching process with extensible dies, Proceedings of the Institution of Mechanical Engineers, Part C: Journal of Mechanical Engineering Science, DOI: 10.1177/0954406216660336.

He, X.C., Liu, F.L., Xing, B.Y., Yang, H.Y., Wang, Y.Q., Gu, F.S. and Ball, A., Numerical and experimental investigations of extensible die clinching, The International Journal of Advanced Manufacturing Technology, Vol. 74 (2014a), pp.1229-1236.

He, X.C., Zhao, L., Yang, H.Y., Xing, B.Y., Wang, Y.Q., Deng, C.J., Gu, F.S. and Ball, A., Investigations of strength and energy absorption of clinched joints, Computational Materials Science, Vol. 94 (2014b), pp.58-65.

Lambiase, F., Influence of process parameters in mechanical clinching with extensible dies, The International Journal of Advanced Manufacturing Technology, Vol. 66 (2013), pp.2123-2131.

Lambiase, F., Clinch joining of heat-treatable aluminum AA6082-T6 alloy under warm conditions, Journal of Materials Processing Technology, Vol. 225 (2015), pp.421-432.

Lambiase, F. and Ko, D.C., Two-steps clinching of aluminum and Carbon Fiber Reinforced Polymer Sheets, Composite Structures, Vol. 164 (2017), pp.180-188.

Lambiase, F. and Ko, D.C., Feasibility of mechanical clinching for joining aluminum AA6082-T6 and Carbon Fiber Reinforced Polymer sheets, Materials and Design, Vol. 107 (2016a), pp.341-352.

Lambiase, F. and Di Llio, A., Finite element analysis of material flow in mechanical clinching with extensible dies, Journal of Materials Engineering and Performance, Vol. 22 (2013), pp.1629-1636.

Lambiase, F. and Di Ilio, A., An experimental study on clinched joints realized with different dies, Thin-walled Structures, Vol. 85 (2014), pp.71-80.

Lambiase, F. and Di Ilio, A., Mechanical clinching of metal-polymer joints, Journal of Materials Processing Technology, Vol. 215 (2015), pp.12-19.

Lambiase, F., Di Ilio, A. and Paoletti, A., Joining aluminium alloys with reduced ductility by mechanical clinching, The International Journal of Advanced Manufacturing Technology, Vol. 77 (2015), pp.1295-1304.

Lambiase, F., Durante, M. and Di Ilio, A., Fast joining of aluminum sheets with Glass Fiber Reinforced Polymer (GFRP) by mechanical clinching, Journal of Materials Processing Technology, Vol. 236 (2016b), pp.241-251.

Lee, C.J., Kim, J.Y., Lee, S.K., Ko, D.C. and Kim, B.M., Design of mechanical clinching tools for joining of aluminium alloy sheets, Materials and Design, Vol. 31 (2010), pp.1854-1861.

Neugebauer, R, Todtermuschke, R., Mauermann, R. and Riedel, F., Overview on the state of development and the application potential of dieless mechanical joining processes, Archives of Civil and Mechanical Engineering, Vol.8, No.4 (2008), pp.51-60.

Oudjene, M., Ben-Ayed, L., Delamézière, A. and Batoz, J.-1., Shape optimization of clinching tools using the response surface methodology with Moving Least-Square approximation, Journal of Materials Processing Technology, Vol. 209 (2009), pp.289-296.

Wen, T., Wang, H., Yang, C. and Liu, L.T., On a reshaping method of clinched joints to reduce the protrusion height, The International Journal of Advanced Manufacturing Technology, Vol. 71 (2014), pp.1709-1715.

Xing, B.Y., He, X.C., Wang, Y.Q., Yang, H.Y. and Deng, C.J., Study of mechanical properties for copper alloy H62 sheets joined by self-piercing riveting and clinching, Journal of Materials Processing Technology, Vol. 216 (2015), pp.28-36.

Zhang, Y, He, X.C., Zeng, K., Lei, L., Gu, F.S. and Ball, A., Influence of heat treatment on mechanical properties of clinched joints in titanium alloy sheets, The International Journal of Advanced Manufacturing Technology, Vol. 91 (2017), pp.3349-3361. 